\title{
Lipoprotein Lipase Polymorphism rs10503669 is Associated with High-density Lipoprotein Cholesterol Levels in Korean Population
}

\author{
Jae Woong Sull ${ }^{1}$, Yong-Bin Eom ${ }^{2}$ and Sun Ha Jee ${ }^{3, \dagger}$ \\ ${ }^{I}$ Department of Biomedical Laboratory Science, College of Health Sciences, Eulji University, \\ Seongnam 461-713, Korea \\ ${ }^{2}$ Department of Biomedical Laboratory Science, College of Medical Sciences, \\ Soonchunhyang University, Asan, Chungnam 336-745, Korea \\ ${ }^{3}$ Department of Epidemiology and Health Promotion, Institute for Health Promotion, \\ Graduate School of Public Health, Yonsei University, Seoul 120-752, Korea
}

\begin{abstract}
High-density lipoprotein (HDL) cholesterol levels are associated with decreased risk of coronary artery disease. Several genome-wide association studies (GWAS) for HDL cholesterol levels have implicated Lipoprotein lipase (LPL) as possibly being causal. Herein, the association between single nucleotide polymorphism (SNP) rs10503669 in the LPL gene and HDL cholesterol levels and triglyceride levels was tested in the Korean population. A total of 994 subjects from Seoul City were included in a replication study with LPL SNP rs10503669. SNP rs10503669 in the LPL gene was associated with mean HDL cholesterol levels (effect per allele $3.13 \mathrm{mg} / \mathrm{dL}, P<0.0001$ ) and triglyceride levels (effect per allele $-18.0 \mathrm{mg} / \mathrm{dL}, P=0.0026$ ). Subjects with the CA/AA genotype had a 0.42 -fold (range $0.23 \sim 0.77$-fold) lower risk of having abnormal HDL cholesterol levels $(<40 \mathrm{mg} / \mathrm{dL})$ than subjects with the CC genotype. When analyzed by gender, the association of LPL was stronger in men than in women. This study clearly demonstrates that genetic variants in $L P L$ influence HDL cholesterol levels and triglyceride levels in Korean adults.
\end{abstract}

Key Words: HDL-cholesterol, LPL, Polymorphisms

\section{INTRODUCTION}

High-density lipoprotein (HDL) cholesterol levels are associated with decreased risk of cardiovascular disease (Pekkanen et al., 1990; Assmann and Gotto, 2004; Teramoto et al., 2008). Several genome-wide association studies (GWAS) for HDL cholesterol levels have reported that Lipoprotein lipase (LPL) (MIM 609708) gene is one of candidate genes (Kathiresan et al., 2008; Kooner et al.

\footnotetext{
*Received: November 7, 2014 / Revised: December 15, 2014

Accepted: December 17, 2014

${ }^{\dagger}$ Corresponding author: Sun Ha Jee. Department of Epidemiology and Health Promotion, Graduate School of Public Health, Yonsei University, Seoul 120-752, Korea.

Tel: +82-2-2228-1523, Fax: +82-2-365-5118

e-mail: jsunha@yuhs.ac

CThe Korean Society for Biomedical Laboratory Sciences. All rights reserved.
}

2008; Willer et al., 2008; Aulchenko et al., 2009; Sabatti et al., 2009; Teslovich et al., 2010). Continental Asian populations tend to have lower levels of serum cholesterol than Europeans (Jee et al., 1999; Suh et al., 2001). Recent GWAS studies in Asian populations reported that SNPs in LPL showed strong evidence of association with HDL cholesterol levels as well as triglyceride levels. Kim et al. identified an SNP on chromosome 8p21.3, rs10503669, as having significant association with triglyceride and HDL cholesterol levels (Kim et al., 2011). However, they did not analyze the association of rs 10503660 with HDL cholesterol by other risk factors like smoking status and body mass index.

Lipoprotein lipase (LPL) is a key enzyme in the metabolism of lipoproteins. It hydrolyzes plasma lipoprotein triglycerides (TG) into free fatty acids and glycerol (Goldberg, 
1996). In this study, the association of HDL cholesterol levels and triglyceride levels with LPL SNP rs10503669 was analyzed on a sample of volunteers from the Korean Metabolic Syndrome Research Initiative Study in Seoul. The association was also analyzed by body mass index level and smoking status.

\section{MATERIALS AND METHODS}

\section{Study population}

Subjects for the GWAS were recruited from the Korean Metabolic Syndrome Research Initiative study in Seoul city, which was initiated in December 2005. A total of 9,128 individuals were recruited in 2006 and an additional 17,569 individuals were recruited in 2007 , for a total cohort of 26,697 volunteers (Yoon et al., 2008; Sull et al., 2009; Jee et al., 2010). Volunteers from the first round underwent routine health examinations at health promotion centers in university hospitals between January 2006 and December 2007. From this group, 6,563 individuals were randomly selected for measurement of adiponectin levels. The subject characteristics were described in a previous study (Jee et al., 2010). In brief, of the 6,563 individuals whose adiponectin was measured, 1,004 individuals were genotyped. The 1,004 subjects were all healthy individuals who were not undergoing any type of lipid-lowering therapy. The protocols of this study were approved by the Institutional Review Board of Human Research at Yonsei University, and written informed consent was obtained from all subjects prior to enrollment.

\section{Data collection}

Participants were interviewed using a structured questionnaire to collect personal histories of cigarette smoking (never smoked, ex-smoker, or current smoker), and demographic characteristics (age, gender, etc.). Waist circumference was measured midway between the lower rib and iliac crest. For measurements of weight and height, light clothing was worn. Body mass indices were calculated as the subject's weight $(\mathrm{kg})$ divided by the square of the subject's height $\left(\mathrm{m}^{2}\right)$.

For clinical chemistry assays, serum was separated from peripheral venous blood samples obtained from each participant after 12-hour fast and stored at $-70^{\circ} \mathrm{C}$ until use. Biomarkers of metabolic syndrome, including fasting blood glucose, total cholesterol (TC), triglycerides (TG), and highdensity lipoprotein cholesterol (HDL-C) were measured with a Hitachi-7600 analyzer (Hitachi, Ltd., Tokyo, Japan). Quality control of the data was conducted in accordance with the procedures recommended by the Korean Association of participant Laboratory Quality Control.

\section{Genotyping assays}

Samples from the Seoul city cohort were genotyped on the Affymetrix Genome-Wide Human SNP (array 5.0) at DNALink. Internal quality control (QC) measures were used for the data obtained: the QC call rate (Dynamic Model algorithm) always exceeded $86 \%$. Genotype calling was carried out using the Birdseed (v2) algorithm. A total of 1,004 individuals were genotyped using this platform. Ten of the 1,004 individuals were removed due to low genotyping call rates $(<95 \%)$, leaving a total of 994 individuals for the genome-wide analysis.

\section{Statistical analysis}

LPL gene SNP rs10503669 was tested for possible effects on HDL cholesterol levels under an additive model in PLINK. Multivariate linear regression models used herein incorporated covariates (age and sex). Multiple logistic regression analysis was also performed. Odds ratios (ORs) with 95\% confidence intervals (CIs) were calculated to examine the association of the $L P L$ SNP with abnormal HDL cholesterol levels ( $<40 \mathrm{mg} / \mathrm{dL}$ for males and $<50 \mathrm{mg}$ / dL for females) (NCEP ATP III). The analyses were also conducted using SAS statistical software, version 9.2 (SAS Institute, Cary, NC). All statistical tests were two-sided, and the statistical significance was determined as $P<0.05$.

\section{RESULTS}

Mean age was 41.9 for male subjects and 41.1 for female subjects (Table 1). On average, this sample of Korean volunteers had low HDL cholesterol levels. Mean levels of HDL cholesterol in the dataset were lower in males (49.8 
$\mathrm{mg} / \mathrm{dL})$ than in females $(59.9 \mathrm{mg} / \mathrm{dL})$. About $10.6 \%$ of the individuals had abnormal HDL cholesterol levels $(<40$ $\mathrm{mg} / \mathrm{dL}$ ). Of the sample dataset, $46.5 \%$ of men and $3.9 \%$ of women were current smokers.

Table 2 shows the $P$ values from a linear regression model for HDL cholesterol levels in the cohort sample when age and sex were included as covariates. SNP rs10503669 in the LPL gene was found to be associated with mean HDL cholesterol levels (effect per allele $3.13 \mathrm{mg} / \mathrm{dL}, P<0.0001$ ) and triglyceride levels (effect per allele $-18.0 \mathrm{mg} / \mathrm{dL}, P=$

Table 1. General characteristics of study population

\begin{tabular}{|c|c|c|}
\hline \multicolumn{2}{|l|}{ Subjects } & Seoul City \\
\hline \multicolumn{2}{|l|}{$\mathrm{N}$} & 994 \\
\hline \multirow{2}{*}{\multicolumn{2}{|c|}{ Male gender (\%) }} & 56.4 \\
\hline & & Mean \pm SD \\
\hline \multicolumn{2}{|l|}{ Age, year } & $41.5 \pm 8.5$ \\
\hline \multicolumn{2}{|c|}{ Waist circumference, $\mathrm{cm}$} & $81.1 \pm 9.7$ \\
\hline \multicolumn{2}{|c|}{ Body mass index, $\mathrm{kg} / \mathrm{m}^{2}$} & $23.7 \pm 3.1$ \\
\hline \multicolumn{2}{|c|}{ Fasting blood sugar, mg/Dl } & $93.8 \pm 16.4$ \\
\hline \multicolumn{2}{|c|}{ Systolic blood pressure, $\mathrm{mmHg}$} & $120.9 \pm 13.8$ \\
\hline \multicolumn{2}{|c|}{ Diastolic blood pressure, $\mathrm{mmHg}$} & $73.9 \pm 10.4$ \\
\hline \multicolumn{2}{|c|}{ HDL cholesterol, mg/dL } & $54.2 \pm 12.9$ \\
\hline \multicolumn{2}{|c|}{ LDL cholesterol, mg/Dl } & $108.7 \pm 29.2$ \\
\hline \multirow{2}{*}{\multicolumn{2}{|c|}{ Triglyceride, mg/dL }} & $118.1 \pm 93.4$ \\
\hline & & $\mathrm{N}(\%)$ \\
\hline \multirow[t]{3}{*}{ Smoking status } & Non & $550(55.3)$ \\
\hline & Ex & $166(16.7)$ \\
\hline & Current & $278(28.0)$ \\
\hline \multirow[t]{2}{*}{ HDL cholesterol } & Normal ( $\geq 40$ mg/dL) & $889(89.4)$ \\
\hline & Abnormal (<40 mg/dL) & $105(10.6)$ \\
\hline
\end{tabular}

SD: standard deviation
0.0026).

The association of LPL gene SNP rs10503669 with abnormal HDL cholesterol levels was also examined (Table 3). Subjects with the CA/AA genotype had a 0.42 -fold (range $0.23 \sim 0.77$-fold) lower risk of having abnormal HDL cholesterol levels $(<40 \mathrm{mg} / \mathrm{dL})$ than subjects with the CC genotype. When analyzed by gender, the association of LPL was stronger in men than in women. Analysis by BMI median level and smoking status in male subjects is presented in Table 4. The association of LPL was a bit stronger in subjects with $\mathrm{BMI} \geq 24.3$ than in subjects with $\mathrm{BMI}<24.3$, but they showed similar trends. The association of LPL was stronger in heavy smokers $(\geq 11 /$ day $)(P=0.0370)$ than non or light smokers $(1 \sim 10 /$ day $)(P=0.0963)$.

\section{DISCUSSION}

In a cohort of 994 subjects, SNP rs10503669 near LPL was associated with increased HDL, consistent with previous studies. Recently, in a GWAS by the Korea Association Resource (KARE) consortium, SNP rs10503669 in LPL showed strong evidence of association with HDL cholesterol level $\left(P=8.4 \times 10^{-43}\right)$ and triglyceride levels $(P=6.84 \times$ $10^{-39}$ ) (Kim et al., 2011). However, a more moderate association of the SNP was observed herein. One possible reason for the difference in result is that the subjects included in this study were almost 10 years younger on average than the KARE study subjects. The mean HDL cholesterol levels in the present study were also much higher than in the KARE subjects. Another recent Korean study also reported similar results for rs10503669 with HDL cholesterol in replication data $\left(P=8.48 \times 10^{-3}\right)$ (Go et al.,

Table 2. Association of LPL gene SNP rs10503669 with Lipid levels based on linear regression model

\begin{tabular}{|c|c|c|c|c|c|}
\hline \multirow{3}{*}{ Phenotypes } & \multicolumn{3}{|c|}{ Genotypes } & \multirow{3}{*}{$\begin{array}{c}\text { Effect } \\
(\mathrm{mg} / \mathrm{dL})\end{array}$} & \multirow{3}{*}{$P$-value ${ }^{*}$} \\
\hline & $\begin{array}{c}\mathrm{CC} \\
(\mathrm{N}=769)\end{array}$ & $\begin{array}{c}\mathrm{CA} \\
(\mathrm{N}=208)\end{array}$ & $\begin{array}{c}\mathrm{AA} \\
(\mathrm{N}=17)\end{array}$ & & \\
\hline & Mean \pm SD & Mean \pm SD & Mean \pm SD & & \\
\hline HDL cholesterol, mg/dL & $53.4 \pm 12.8$ & $56.5 \pm 13.0$ & $59.5 \pm 10.9$ & 3.13 & $<0.0001$ \\
\hline Triglyceride, mg/dL & $122.1 \pm 100.1$ & $107.0 \pm 65.6$ & $71.6 \pm 23.7$ & -18.0 & 0.0026 \\
\hline LDL cholesterol, mg/dL & $109.1 \pm 29.2$ & $108.1 \pm 29.9$ & $98.1 \pm 18.9$ & -2.43 & 0.2087 \\
\hline
\end{tabular}

Estimated effect size $(\beta)$ and $P$-value in multiple linear regression model, considering age and sex under an additive model. 
Table 3. Odds ratio (OR) of polymorphic genotypes of LPL rs10503669 on HDL cholesterol levels ${ }^{\mathrm{a}}$ in Severance data (N=994)

\begin{tabular}{|c|c|c|c|c|c|}
\hline \multirow{2}{*}{ Subjects } & \multirow{2}{*}{ Genotype } & \multirow{2}{*}{$\begin{array}{c}\text { Normal }(\geq 40 \mathrm{mg} / \mathrm{dL}) \\
N(\%)\end{array}$} & \multicolumn{3}{|c|}{ Abnormal $(<40 \mathrm{mg} / \mathrm{dL})^{*}$} \\
\hline & & & $N(\%)$ & $\mathrm{OR}\left(95 \% \mathrm{CI}^{\mathrm{b}}\right)$ & $P$-value \\
\hline \multirow[t]{2}{*}{ All } & $\mathrm{CC}$ & $677(76.2)$ & $92(87.6)$ & 1.00 (reference) & \\
\hline & $\mathrm{CA} / \mathrm{AA}$ & $212(23.8)$ & $13(12.4)$ & $0.42(0.23 \sim 0.77)$ & 0.0051 \\
\hline \multirow[t]{2}{*}{ Men } & $\mathrm{CC}$ & $350(74.8)$ & $82(88.2)$ & 1.00 (reference) & \\
\hline & $\mathrm{CA} / \mathrm{AA}$ & $118(25.2)$ & $11(11.8)$ & $0.38(0.20 \sim 0.75)$ & 0.0047 \\
\hline \multirow[t]{2}{*}{ Women } & $\mathrm{CC}$ & $260(77.4)$ & $77(79.4)$ & 1.00 (reference) & \\
\hline & CA/AA & $76(22.6)$ & $20(20.6)$ & $0.90(0.51 \sim 1.56)$ & 0.6989 \\
\hline
\end{tabular}

${ }^{\mathrm{a}}$ Adjusted for age and sex $\quad{ }^{\mathrm{b}} \mathrm{CI}$ : Confidence interval

*Abnormal HDL cholesterol levels were defined as $<50 \mathrm{mg} / \mathrm{dL}$ for women

Table 4. Odds ratio (OR) of polymorphic genotypes of LPL rs10503669 on HDL cholesterol levels in Korean Men (N=561)

\begin{tabular}{|c|c|c|c|c|c|}
\hline \multirow{2}{*}{ Subjects } & \multirow{2}{*}{ Genotype } & \multirow{2}{*}{$\frac{\operatorname{Normal}(\geq 40 \mathrm{mg} / \mathrm{dL})}{N(\%)}$} & \multicolumn{3}{|c|}{ Abnormal (<40 mg/dL) } \\
\hline & & & $N(\%)$ & $\mathrm{OR}\left(95 \% \mathrm{CI}^{\mathrm{b}}\right)$ & $P$-value \\
\hline \multirow[t]{2}{*}{$\mathrm{BMI}<24.3$} & $\mathrm{CC}$ & $185(72.8)$ & $22(84.6)$ & 1.00 (reference) & \\
\hline & CA/AA & $69(27.2)$ & $4(15.4)$ & $0.44(0.15 \sim 1.35)$ & 0.1522 \\
\hline \multirow[t]{2}{*}{$\mathrm{BMI} \geq 24.3$} & $\mathrm{CC}$ & $165(77.1)$ & $60(89.6)$ & 1.00 (reference) & \\
\hline & CA/AA & 49 (22.9) & $7(10.4)$ & $0.39(0.17 \sim 0.90)$ & 0.0275 \\
\hline \multirow[t]{2}{*}{ Non or light smokers $(1 \sim 10 /$ day $)$} & $\mathrm{CC}$ & $167(80.7)$ & $36(92.3)$ & 1.00 (reference) & \\
\hline & CA/AA & $40(19.3)$ & $3(7.7)$ & $0.35(0.10 \sim 1.21)$ & 0.0963 \\
\hline \multirow[t]{2}{*}{ Ex smokers } & $\mathrm{CC}$ & $88(69.3)$ & $21(80.8)$ & 1.00 (reference) & \\
\hline & $\mathrm{CA} / \mathrm{AA}$ & $39(30.7)$ & $5(19.2)$ & $0.54(0.19 \sim 1.52)$ & 0.2411 \\
\hline \multirow[t]{2}{*}{ Heavy smokers ( $\geq 11 /$ day) } & $\mathrm{CC}$ & $92(71.3)$ & $24(88.9)$ & 1.00 (reference) & \\
\hline & $\mathrm{CA} / \mathrm{AA}$ & $37(28.7)$ & $3(11.1)$ & $0.25(0.07 \sim 0.69)$ & 0.0370 \\
\hline
\end{tabular}

${ }^{\mathrm{a}}$ Adjusted for age $\quad{ }^{\mathrm{b}} \mathrm{CI}$ : Confidence interval

2012).

The associations between genotypes and phenotypes can be modified by gene-environment interactions. Effect modification of the associations between LPL SNPs and serum lipid concentrations by interactions with cigarette smoking has been reported (Lee et al., 2004; Kathiresan et al., 2008; Kooner et al., 2008; Pyun et al., 2012; Mo et al., 2013). In the present study, association of the LPL SNP with HDL cholesterol by smoking status was also examined. The association was a little stronger in current heavy smokers than non or light smokers. The association by body mass index median value was also examined, but the association was similar. In a cohort study of 22,939 healthy US women of European ancestry, the effects of common variants in the LPL gene on HDL-C levels were modified by physical activity (Ahmad et al., 2011).
The LPL gene is comprised of 10 exons spanning about $30 \mathrm{~kb}$, with exon 10 specifying the entire 3-prime untranslated sequence (Deeb and Peng, 1989; Monsalve et al., 1990). Differences in the frequency of rs 10503669 have been found between different populations. The A allele frequency was $11.5 \%$ in Europeans, while being much lower in sub-saharan Africans (4\%) and Mexican Americans (6\%). The frequency in East Asians was 8.1\% in CHB (Han Chinese in Beijing), and $11.6 \%$ in Japanese according to HapMap data. In the present study, the frequency was $12.0 \%$ (NCBI website).

The lack of association between the previously reported loci and HDL cholesterol levels in our study may be attributable to the insufficient statistical power of the cohort data. Genetic studies of lipid levels in Asian populations may not necessarily identify the same set of susceptibility genes as those in European-derived populations. However, 
this Korean cohort showed evidence that the LPL gene on chromosome 8 is associated with serum HDL cholesterol levels as well as triglycerides levels.

\section{Acknowledgements}

This research was supported by Basic Science Research Program through the National Research Foundation of Korea (NRF) funded by the Ministry of Education, Science and Technology (2012010044).

\section{REFERENCES}

Ahmad T, Chasman DI, Buring JE, Lee IM, Ridker PM, Everett BM. Physical activity modifies the effect of LPL, LIPC, and CETP polymorphisms on HDL-C levels and the risk of myocardial infarction in women of European ancestry. Circ Cardiovasc Genet. 2011. 4: 74-80.

Assmann G, Gotto AM Jr. HDL cholesterol and protective factors in atherosclerosis. Circulation. 2004. 109: III8-III14.

Aulchenko YS, Ripatti S, Lindqvist I, Boomsma D, Heid IM, Pramstaller PP, Penninx BW, Janssens AC, Wilson JF, Spector T, Martin NG, Pedersen NL, Kyvik KO, Kaprio J, Hofman A, Freimer NB, Jarvelin MR, Gyllensten U, Campbell H, Rudan I, Johansson A, Marroni F, Hayward C, Vitart V, Jonasson I, Pattaro C, Wright A, Hastie N, Pichler I, Hicks AA, Falchi M, Willemsen G, Hottenga JJ, de Geus EJ, Montgomery GW, Whitfield J, Magnusson P, Saharinen J, Perola M, Silander K, Isaacs A, Sijbrands EJ, Uitterlinden AG, Witteman JC, Oostra BA, Elliott P, Ruokonen A, Sabatti C, Gieger C, Meitinger T, Kronenberg F, Döring A, Wichmann HE, Smit JH, McCarthy MI, van Duijn CM, Peltonen L. ENGAGE Consortium. Loci influencing lipid levels and coronary heart disease risk in 16 European population cohorts. Nat Genet. 2009. 41: 47-55.

Deeb SS, Peng RL. Structure of the human lipoprotein lipase gene. Biochemistry. 1989. 28: 4131-4135.

Monsalve MV, Henderson H, Roederer G, Julien P, Deeb S, Kastelein JJ, Peritz L, Devlin R, Bruin T, Murthy MR. A missense mutation at codon 188 of the human lipoprotein lipase gene is a frequent cause of lipoprotein lipase deficiency in persons of different ancestries. J Clin Invest. 1990. 86: 728-734.

Go MJ, Hwang JY, Kim DJ, Lee HJ, Jang HB, Park KH, Song J, Lee JY. Effect of genetic predisposition on blood lipid traits using cumulative risk assessment in the korean population.
Genomics Inform. 2012. 10: 99-105.

Goldberg IJ. Lipoprotein lipase and lipolysis: central roles in lipoprotein metabolism and atherogenesis. J Lipid Res. 1996. 37: 693-707.

Jee SH, Suh I, Kim IS, Appel LJ. Smoking and atherosclerotic cardiovascular disease in men with low levels of serum cholesterol: the Korea Medical Insurance Corporation Study. JAMA. 1999. 282: 2149-2155.

Jee SH, Sull JW, Lee JE, Shin C, Park J, Kimm H, Cho EY, Shin ES, Yun JE, Park JW, Kim SY, Lee SJ, Jee EJ, Baik I, Kao L, Yoon SK, Jang Y, Beaty TH. Adiponectin concentrations: a genome-wide association study. Am J Hum Genet. 2010. 87: 545-552.

Kathiresan S, Melander O, Guiducci C, Surti A, Burtt NP, Rieder MJ, Cooper GM, Roos C, Voight BF, Havulinna AS, Wahlstrand B, Hedner T, Corella D, Tai ES, Ordovas JM, Berglund G, Vartiainen E, Jousilahti P, Hedblad B, Taskinen MR, Newton-Cheh C, Salomaa V, Peltonen L, Groop L, Altshuler DM, Orho-Melander M. Six new loci associated with blood low-density lipoprotein cholesterol, high-density lipoprotein cholesterol or triglycerides in humans. Nat Genet. 2008. 40: 189-197.

Kim YJ, Go MJ, Hu C, Hong CB, Kim YK, Lee JY, Hwang JY, Oh JH, Kim DJ, Kim NH, Kim S, Hong EJ, Kim JH, Min H, Kim Y, Zhang R, Jia W, Okada Y, Takahashi A, Kubo M, Tanaka T, Kamatani N, Matsuda K, MAGIC consortium, Park T, Oh B, Kimm K, Kang D, Shin C, Cho NH, Kim HL, Han BG, Lee JY, Cho YS. Large-scale genome-wide association studies in east Asians identify new genetic loci influencing metabolic traits. Nat Genet. 2011. 43: 990-995.

Kooner JS, Chambers JC, Aguilar-Salinas CA, Hinds DA, Hyde CL, Warnes GR, Gómez Pérez FJ, Frazer KA, Elliott P, Scott J, Milos PM, Cox DR, Thompson JF. Genome-wide scan identifies variation in MLXIPL associated with plasma triglycerides. Nat Genet. 2008. 40: 149-151.

Lee J, Tan CS, Chia KS, Tan CE, Chew SK, Ordovas JM, Tai ES. The lipoprotein lipase S447X polymorphism and plasma lipids: interactions with APOE polymorphisms, smoking, and alcohol consumption. J Lipid Res. 2004. 45: 1132-1139.

Mo X, Liu X, Wang L, Lu X, Chen S, Li H, Huang J, Chen J, Cao J, Li J, Tang Y, Gu D. Association of lipoprotein lipase polymorphism rs2197089 with serum lipid concentrations and LPL gene expression. J Hum Genet. 2013. 58: 160-164.

Pekkanen J, Linn S, Heiss G, Suchindran CM, Leon A, Rifkind BM, Tyroler HA. Ten-year mortality from cardiovascular 
disease in relation to cholesterol level among men with and without preexisting cardiovascular disease. N Engl J Med. 1990. 322: 1700-1707.

Pyun JA, Kim S, Park K, Baik I, Cho NH, Koh I, Lee JY, Cho YS, Kim YJ, Go MJ, Shim E, Kwack K, Shin C. Interaction Effects of Lipoprotein Lipase Polymorphisms with Lifestyle on Lipid Levels in a Korean Population: A Cross-sectional Study. Genomics Inform. 2012. 10: 88-98.

Sabatti C, Service SK, Hartikainen AL, Pouta A, Ripatti S, Brodsky J, Jones CG, Zaitlen NA, Varilo T, Kaakinen M, Sovio U, Ruokonen A, Laitinen J, Jakkula E, Coin L, Hoggart C, Collins A, Turunen H, Gabriel S, Elliot P, McCarthy MI, Daly MJ, Järvelin MR, Freimer NB, Peltonen L. Genome-wide association analysis of metabolic traits in a birth cohort from a founder population. Nat Genet. 2009. 41: 35-46.

Suh I, Jee SH, Kim HC, Nam CM, Kim IS, Appel LJ. Low serum cholesterol and haemorrhagic stroke in men: Korea Medical Insurance Corporation Study. Lancet. 2011. 357: 922-925.

Sull JW, Kim HJ, Yun JE, Kim G, Park EJ, Kim S, Lee HY, Jee $\mathrm{SH}$. Serum adiponectin is associated with family history of diabetes independently of obesity and insulin resistance in healthy Korean men and women. Eur J Endocrinol. 2009. 160: 39-43.

Teramoto T, Ohashi Y, Nakaya N, Yokoyama S, Mizuno K, Nakamura H. Practical risk prediction tools for coronary heart disease in mild to moderate hypercholesterolemia in Japan: Originated from the MEGA study data. Circ J. 2008. 72: 1569-1575.

Teslovich TM, Musunuru K, Smith AV, Edmondson AC, Stylianou IM, Koseki M, Pirruccello JP, Ripatti S, Chasman DI, Willer CJ, Johansen CT, Fouchier SW, Isaacs A, Peloso GM, Barbalic M, Ricketts SL, Bis JC, Aulchenko YS, Thorleifsson G, Feitosa MF, Chambers J, Orho-Melander M, Melander O, Johnson T, Li X, Guo X, Li M, Shin Cho Y, Jin Go M, Jin Kim Y, Lee JY, Park T, Kim K, Sim X, Twee-Hee Ong R, CroteauChonka DC, Lange LA, Smith JD, Song K, Hua Zhao J, Yuan X, Luan J, Lamina C, Ziegler A, Zhang W, Zee RY, Wright AF, Witteman JC, Wilson JF, Willemsen G, Wichmann HE, Whitfield JB, Waterworth DM, Wareham NJ, Waeber G, Vollenweider P, Voight BF, Vitart V, Uitterlinden AG, Uda M, Tuomilehto J, Thompson JR, Tanaka T, Surakka I, Stringham HM, Spector TD, Soranzo N, Smit JH, Sinisalo J, Silander K, Sijbrands EJ, Scuteri A, Scott J, Schlessinger D, Sanna S, Salomaa V, Saharinen J, Sabatti C, Ruokonen A, Rudan I, Rose LM, Roberts R, Rieder M, Psaty BM, Pramstaller PP,
Pichler I, Perola M, Penninx BW, Pedersen NL, Pattaro C, Parker AN, Pare G, Oostra BA, O'Donnell CJ, Nieminen MS, Nickerson DA, Montgomery GW, Meitinger T, McPherson R, McCarthy MI, McArdle W, Masson D, Martin NG, Marroni F, Mangino M, Magnusson PK, Lucas G, Luben R, Loos RJ, Lokki ML, Lettre G, Langenberg C, Launer LJ, Lakatta EG, Laaksonen R, Kyvik KO, Kronenberg F, König IR, Khaw KT, Kaprio J, Kaplan LM, Johansson A, Jarvelin MR, Janssens AC, Ingelsson E, Igl W, Kees Hovingh G, Hottenga JJ, Hofman A, Hicks AA, Hengstenberg C, Heid IM, Hayward C, Havulinna AS, Hastie ND, Harris TB, Haritunians T, Hall AS, Gyllensten U, Guiducci C, Groop LC, Gonzalez E, Gieger C, Freimer NB, Ferrucci L, Erdmann J, Elliott P, Ejebe KG, Döring A, Dominiczak AF, Demissie S, Deloukas P, de Geus EJ, de Faire U, Crawford G, Collins FS, Chen YD, Caulfield MJ, Campbell H, Burtt NP, Bonnycastle LL, Boomsma DI, Boekholdt SM, Bergman RN, Barroso I, Bandinelli S, Ballantyne CM, Assimes TL, Quertermous T, Altshuler D, Seielstad M, Wong TY, Tai ES, Feranil AB, Kuzawa CW, Adair LS, Taylor HA Jr, Borecki IB, Gabriel SB, Wilson JG, Holm H, Thorsteinsdottir U, Gudnason V, Krauss RM, Mohlke KL, Ordovas JM, Munroe PB, Kooner JS, Tall AR, Hegele RA, Kastelein JJ, Schadt EE, Rotter JI, Boerwinkle E, Strachan DP, Mooser V, Stefansson K, Reilly MP, Samani NJ, Schunkert H, Cupples LA, Sandhu MS, Ridker PM, Rader DJ, van Duijn CM, Peltonen L, Abecasis GR, Boehnke M, Kathiresan S. Biological, clinical and population relevance of 95 loci for blood lipids. Nature. 2010. 466: 707-713.

Willer CJ, Sanna S, Jackson AU, Scuteri A, Bonnycastle LL, Clarke R, Heath SC, Timpson NJ, Najjar SS, Stringham HM, Strait J, Duren WL, Maschio A, Busonero F, Mulas A, Albai G, Swift AJ, Morken MA, Narisu N, Bennett D, Parish S, Shen H, Galan P, Meneton P, Hercberg S, Zelenika D, Chen WM, Li Y, Scott LJ, Scheet PA, Sundvall J, Watanabe RM, Nagaraja R, Ebrahim S, Lawlor DA, Ben-Shlomo Y, Davey-Smith G, Shuldiner AR, Collins R, Bergman RN, Uda M, Tuomilehto J, Cao A, Collins FS, Lakatta E, Lathrop GM, Boehnke M, Schlessinger D, Mohlke KL, Abecasis GR. Newly identified loci that influence lipid concentrations and risk of coronary artery disease. Nat Genet. 2008. 40: 161-169.

Yoon SJ, Lee HS, Lee SW, Yun JE, Kim SY, Cho ER, Lee SJ, Jee EJ, Lee HY, Park J, Kim HS, Jee SH. The association between adiponectin and diabetes in the Korean population. Metabolism. 2008. 57: 853-857. 